Received: November 20, 2017

\title{
Research on the Correlation between Law Teaching Reform and Students' Academic Performance Based on Regression Analysis Method
}

\author{
$\mathrm{Na} \mathrm{Li}^{1}$ \\ Heihe University
}

\begin{abstract}
Legal education bears the important mission of imparting legal knowledge, training legal thinking and cultivating legal talents and the reform of law teaching is also a hot topic in recent years. This paper takes the Law School of a university as an example and investigates the status quo of law teaching effectiveness through questionnaires. This paper uses multiple regression analysis method and Pearson product-moment correlation analysis method to study the correlation between various factors in the reform of law teaching and the academic performance and learning effectiveness of students. The results show that the interpretable variable of the teaching method and technique of teachers for the learning time, learning attitude and academic performance is $5.2 \%, 6.28 \%$ and $19.8 \%$ respectively, indicating that they are important factors influencing the academic performance of students. These two factors are followed by teaching content, teaching management and exams. This study is of great guiding significance for clarifying the direction of law teaching reform and improving the academic performance of students.
\end{abstract}

\section{Keywords}

Law $•$ Teaching Reform • Regression Analysis • Teaching Effectiveness

\footnotetext{
${ }^{1}$ Correspondence to: Li Na (ML), Heihe University, Cultural Tourism Institute, Heihe 164300 China. Email: linabox@163.com

Citation: Li, N. (2018). Research on the Correlation between Law Teaching Reform and Students' Academic Performance Based on Regression Analysis Method. Educational Sciences: Theory \& Practice, 18(5), 1620-1627. http://dx.doi.org/10.12738/estp.2018.5.061
} 
As an important part of education, law education is an important base for exporting practical and legal basic talents to the law circle in China. Unlike other higher education, the law education is also professional (JunPing, 2012). Therefore, in recent years, the reform of law education has become the focus of scholars at home and abroad.

There is a long history for studies on law education in foreign countries. People have attached great emphasis on this study and has obtained fruitful achievements. The "Legal Gate", "Law School", "Law and Revolution" are books on law education (Bain, 1996) and have been translated into Chinese and published in China. The discourse that has a great impact on law education is the European integration and American disintegration. Japan, Germany and other law education powers have a successful legal education mode. Through summarization, the study on law education in foreign countries is mainly concentrated on the research perspective of internal factors such as relational research, integration research and methodology (Bland \& Altman, 1986). In recent years, the domestic research achievements on law education have shown a gradual upward trend. According to the statistics, the total number of master and doctoral dissertations included in the paper database from 1999 to 2006 is 35 (Lewis, Baker \& Helding, 2015) and the total number of papers on law education and law profession included in China Journal Net from 1994 to 2006 is 908 and 173 respectively. The achievements of monograph and coauthor on law education are fruitful, such as "Law Education and the Cultivation of the Practical Ability of Law Student", "Law Education Theory" and "the Road of Chinese Law Education". (Haney, Czerniak \& Lumpe, 1996). It can also be seen from these research results that legal experts and related scholars attach great importance to law education. It can be found through the analysis that the reform of law education can be implemented from subject orientation, standardizing law education, improving the level of law education and regulating the management of law education (Wen-Seng \& Jia-Fang, 2015). However, most of the current research achievements are based on "Legal Education" written by Mr. Sun Xiaolou. This book emphasizes pure theoretical analysis and logical analysis but lacks specific perspective and empirical research, which calls for supplement (Radford, 1998).

Based on the above analysis and referring to relevant literature at home and abroad, this paper takes the students of the Law School of a comprehensive university as the research object and obtains the relevant data through questionnaires with the research object as studying the correlation between law education reform and academic performance of students. Then, the data obtained is analyzed and the results of the correlation analysis and layer-by-layer regression analysis of each influencing factor and the academic performance of students and the learning effectiveness from different dimensions are studied. It draws the conclusion that the impact of teaching method and technique of teachers on the academic performance of students is the most significant. Also, it summarizes the problems existing in current law teaching reform and some thoughts and suggestions on the reform of law teaching and improvement of the academic performance of students are put forward based on the survey result.

\section{Investigation on the Status Quo of Law Teaching Achievements and Analysis of Influencing Factors}




\section{Investigation and Analysis of the Status Quo of Law Teaching}

Introduction to the basic information of survey. This paper selects the students from the Law School of a comprehensive university as the investigation object and conducts questionnaires on the reform of law teaching, the academic performance and learning effectiveness of students. A total of 286 valid questionnaires (98 males and 188 females) are collected with an effective rate of $95.2 \%$. The investigation objects are mainly juniors, accounting for $71 \%$ of the total.

In order to study the influence of different factors of law teaching reform on students' academic performance, this paper takes the classroom teaching effect theory as the basis. Teaching methods and techniques, teaching content, teaching management and examination which are mostly related to the academic performance of students are taken as the influencing factors of the questionnaire. Three dimensions, namely learning attitude, learning method and academic performance are selected to set up the questionnaire (Reid, Nagarajan \& Dortins, 2006) and EXCLE and SPSS are used for the statistical analysis of the survey result.

Survey results and analysis. Figure 1 shows the proportion of the academic performance and learning effectiveness of students at different levels according to the survey result. It can be seen from the Figure that the learning attitude of the surveyed law students is good in general. The proportion of excellent and good learning attitude accounts for about $78 \%$, of which students with excellent learning attitude account for $24.04 \%$. Only $29.43 \%$ of students can ensure sufficient learning time and the learning time of more than half of students is in a general and poor state. The overall academic performance of students is in the general state, reaching $47.68 \%$. Only $3.32 \%$ of students have excellent academic performance and $30.19 \%$ of students have relatively good academic performance.

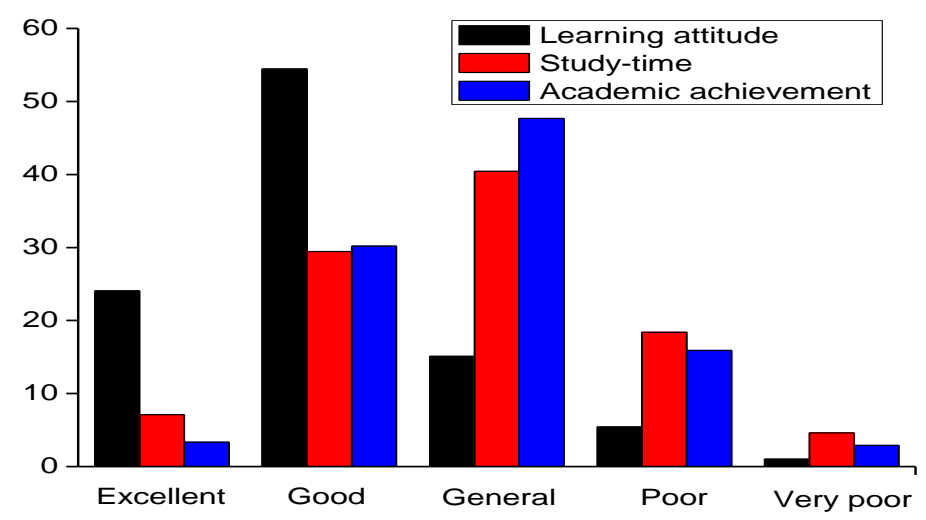

Figure 1. The current situation of law undergraduate classroom teaching.

\section{Correlation Analysis Between Different Influencing Factors and Different Dimensions of the Academic Performance of Students}

In this paper, the Pearson product-moment correlation analysis method is used for the correlation analysis of the relationship between teaching content, method and technique, teaching management and examination and the academic performance and learning effectiveness of students to determine the relationship between them. 
Table 1

Correlation Analysis Table Between Different Influencing Factors and Students' Teaching Achievements

\begin{tabular}{lccc}
\hline & Learning time & Learning attitude & Learning method \\
\hline Teaching content & $.141^{* *}$ & $.258^{* *}$ & $.176^{* *}$ \\
Teaching methods and skills & $.223^{* *}$ & $.249^{* *}$ & $.434^{* *}$ \\
Teaching management and examination & $.146^{* *}$ & $.201^{* *}$ & $.157^{* *}$ \\
\hline
\end{tabular}

Note. The larger the $\mathrm{M}$ value, the greater the effect, the *indicates a significant correlation at the 0.05 level, and $* *$ indicates a significant correlation at the 0.01 level.

It can be seen from Table 1 that there is a significant positive correlation between each influencing factor and the academic performance and learning effectiveness of students and the correlation between academic performance and learning attitude and various factors is more significant.

\section{The Predictive Effect of Law Teaching Reform on Different Dimensions of the Academic Performance}

\section{of Students}

In order to further understand the predictive influence of teaching content, method and technique, teaching management and examination on the academic performance and learning effectiveness of students, this paper uses multiple regression analysis for the layer-bylayer analysis.

Stepwise regression analysis of each factor and the learning time of students. Table 2 shows the stepwise regression analysis table of each factor and the learning time of students. It can be seen from the Table that the teaching method and technique, teaching management and examination, and content all enter the regression equation. The predictive power combined variation of these three factors for the learning time of students is $8.8 \%$, while the predictive power of teaching method and technique is only $5.2 \%$.

Table 2 .

Step-by-step regression analysis of various factors and student learning time

\begin{tabular}{lllllll}
\hline Predictor & $\mathrm{F}$ & $\mathrm{B}$ & $\mathrm{T}$ & $\mathrm{R}$ & $\mathrm{R}^{2}$ & $\Delta \mathbf{R}$ \\
\hline $\begin{array}{l}\text { Teaching methods and } \\
\text { skills }\end{array}$ & $22.813^{* *}$ & $.181^{* *}$ & $3.471^{* *}$ & .232 & .052 & .054 \\
$\begin{array}{l}\text { Teaching management and } \\
\text { examination }\end{array}$ & $16.985^{* *}$ & $.163^{* *}$ & $3.052^{* *}$ & .276 & .079 & .023 \\
\begin{tabular}{l} 
Teaching content \\
\hline
\end{tabular} & $12.925^{* *}$ & $.121^{* *}$ & $2.635^{* *}$ & .298 & .088 & .011 \\
\hline
\end{tabular}

Stepwise regression analysis of each factor and the learning attitude of students. It can be found through the stepwise regression analysis of each factor and the learning attitude of students that only the teaching method and technique enter the regression equation. The analysis results are shown in Figure 2. It can be seen from the Figure that its multiple correlation coefficient is $2.49 \%$ and the variation for learning attitude is $6.28 \%$.

Stepwise regression analysis of each factor and the academic performance of students. It can be found through the stepwise regression analysis of each factor and the academic performance of students that only the teaching method and technique enter the regression equation. The analysis results are shown in Figure 3 . The impact on the academic performance of students is explained as $19.8 \%$. 


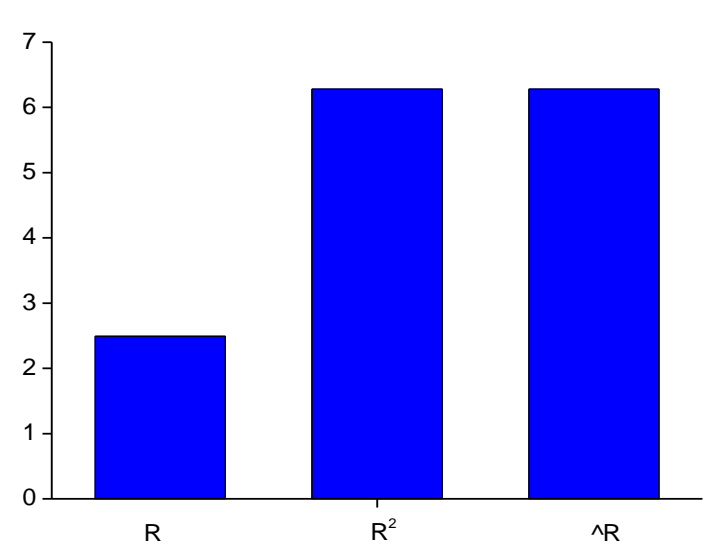

Figure 2. Step-by-step regression analysis of various factors and students' learning attitude.

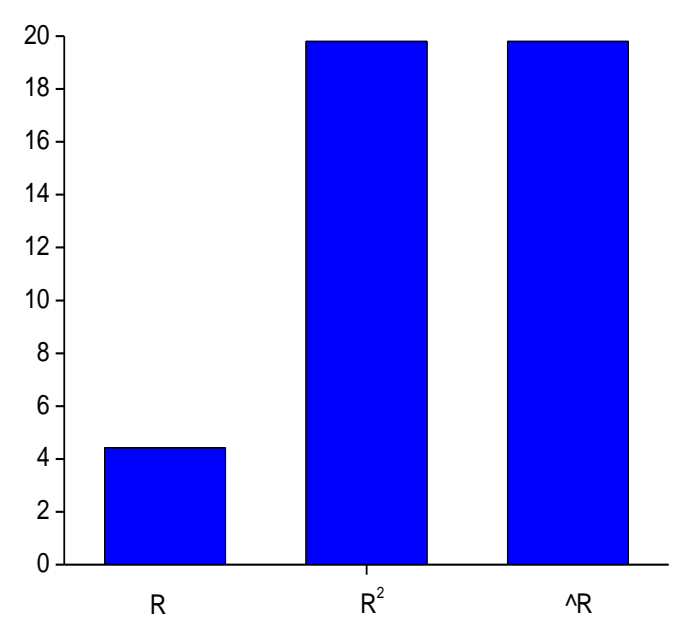

Figure 3. Step-by-step regression analysis of various factors and students' academic academic performance.

Problems. Based on the above analysis results, it can be seen that, the teaching method and technique of teachers have a significant impact on the learning time, learning attitude and academic performance of students in the current law teaching reform process. When teachers use appropriate teaching method and technique, they can improve the learning initiative of students. In addition, problems such as old and boring content, single method and disconnected from the actual situation can be found in the teaching process so that students may lose their learning interest. Thus, they can only do rote memorization before the exam, so their performance is not satisfactory. If the law theory can be combined with practice, it can help students cultivate the ability to analyze and solve problems, which can not only promote students to form good learning habits, but improve the academic performance and learning effectiveness of students of students. Also, good teaching management and examination can better test the ability of students. 


\section{Reflect on Improving the Academic Performance of Students through Law Teaching Reform}

Based on the above investigation and analysis results, this paper believes that the academic performance of law students should be improved from the reform of teaching method and technique of law education, optimization of law teaching content, reform of teaching management and examination of law teaching (Peng, 2011), as shown in Figure 4.

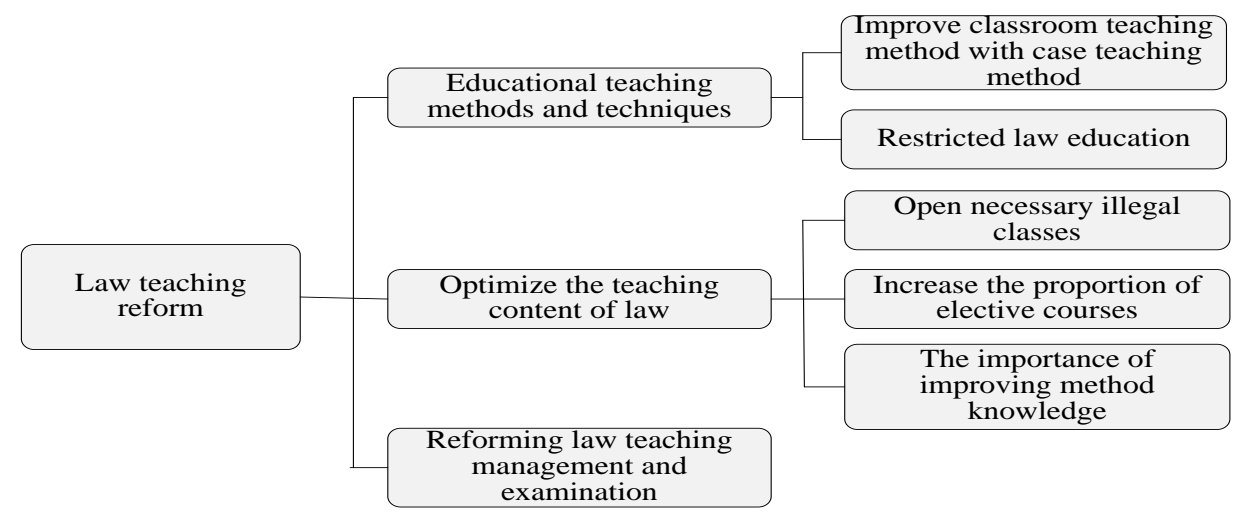

Figure 4. Law teaching reform.

\section{Reforming the Teaching Method and Technique of Law Education}

The traditional simple imparting method, case teaching method and mock court teaching method cannot satisfy the needs of law education reform. No one method is fixed. Therefore, in order to improve the teaching effect, the first thing we need to do is to limit the simple law education, but to explain the content and the essence of the law, which can help students understand the law and its development rules. Secondly, on the basis of traditional imparting method, it should be combined with various teaching methods such as cases, mock court and holiday internship.

\section{Optimizing the Law Teaching Content}

The reform of law teaching content should start from the optimization of the discipline setting. That is, on the basis of professional curriculum of law major, great emphasis should be attached to the setting of non-law courses. The proportion of elective courses should be increase so as to broaden the knowledge scope of students. The traditional center of knowledge imparting should be gradually transformed to increasing the proportion of method knowledge, to cultivate the wisdom of students to use the law flexibly.

\section{Reforming the Teaching Management and Examination of Law Teaching}

Teaching management reform. The law teaching management in China has always been an administrative state management mode and there is a lack of competition among various education departments. In order to change this drawback, the industry management mechanism can be introduced. Firstly, relevant law associations 
can be established. Secondly the management and regulation of the law education system and education management method of the industry association should be strengthened on the basis of state management mode. Finally, the academic committee can be established within the law school and teachers play the role of education management.

Reform of examination system. The traditional examination system is based on exam-taking examination. Students can use a few days before the exam for the preparation, which is not conducive to the cultivation of good learning habits. Therefore, it is necessary to change the traditional written examination to the form of written examination and oral examination. At the same time, the proportion of usual classroom assessment should be increased and the time of usual assessments can be randomly selected or informed one or two days in advance, which is more conducive to the knowledge accumulation of students and the improvement of academic performance and learning effectiveness.

\section{Conclusion}

In order to improve the quality of law classroom teaching and the practical ability of students, this paper studies the correlation between law teaching reform and the academic students of students. The specific conclusions are as follows:

(1) The analysis of the questionnaire shows that the academic performance of $47.68 \%$ of law students is in a general state and the learning attitude is relatively good. However, the learning time of students cannot be guaranteed, and more than half of the students are in a general and poor state.

(2) The result of the Pearson product-moment correlation analysis of the survey data shows that there is significant correlation between the teaching content, method and technique, teaching management and examination and the academic performance and learning effectiveness of students.

(3) The stepwise regression analysis of the survey data shows that that the interpretable variable of the teaching method and technique of teachers for the learning time, learning attitude and academic performance of students is $5.2 \%, 6.28 \%$ and $19.8 \%$ respectively, indicating that they are important factors that affect the academic performance of students.

\section{References}

Bain, L. J. (1966). Applied regression analysis. Technometrics, 9(1), 182-183.

Bland, J. M., \& Altman, D. J. (1986). Regression analysis. Lancet, 327(8486), 908-909.

Haney, J. J., Czerniak, C. M., \& Lumpe, A. T. (1996). Teacher beliefs and intentions regarding the implementation of science education reform strands. Journal of Research in Science Teaching, 33(9), 971993. http://dx.doi. org/ 10.1002 /(SICI)1098-2736(199611)33:9<971::AID-TEA2>3.0.CO;2-S

Jun-ping, W. A. N. G. (2012). The definition of some notions concerning on legal experiment teaching and their application [J]. Journal of Higher Education, 9, 014. 
Lewis, E. B. Baker, D. R., \& Helding, B. A. (2015). Science teaching reform through professional development: teachers' use of a scientific classroom discourse community model. Science Education, 99(5), 896-931.

Olitsky, S. (2015). Facilitating changes in college teaching practices: Instructional reform, identity conflict and professional community in a K-20 partnership. Research in Science Education, 45(4), 625-646.

Peng, Y. (2011). The new teaching requirements and the influence of assessment: A case study of college English reform in china. Malawi Medical Journal, 21(4), 168-173.

Radford, D. L. (1998). Transferring theory into practice: A model for professional development for science education reform. Journal of Research in Science Teaching, 35(1), 73-88. http://dx.doi. org/ 10.1002/(SICI)1098-2736(199801)35:1<73::AID-TEA5>3.0.CO;2-K

Reid, A., Nagarajan, V., \& Dortins, E. (2006). The experience of becoming a legal professional. Higher Education Research \& Development, 25(1), 85-99.

Wen-Seng, Y. U., \& Jia-Fang, L. (2015). An analysis of the model of teaching reform in the primary and secondary schools over the past 35years. Journal of Teacher Education. 